\title{
The Geniai Tuff in the southern East Baltic area - a new correlation tool near the Aeronian/Telychian stage boundary, Llandovery, Silurian
}

\author{
TARMO KIIPLI, Sigitas RAdZIEVIČIUS, TOIVO KAlLASTE, ENLI KIIPLI, SVEN SIIR, Alvar SOESOO \& \\ MARGUS VOOLMA
}

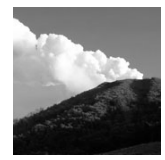

\begin{abstract}
In three drill cores in Latvia and Lithuania a thin ( $1 \mathrm{~cm}$ thick) altered volcanic ash bed with high concentrations of phosphorus (up to $3 \%$ ), cerium (1\%), lanthanum $(0.5 \%)$ and strontium $(2.5 \%)$, has been found close to the Aeronian/Telychian boundary (Llandovery, Silurian, ca $438 \mathrm{Ma}$ ). Small, millimetre-thick lenses within the ash bed contain up to $12 \% \mathrm{P}$ and $\mathrm{Sr}$, up to $6 \% \mathrm{Ce}$ and $3 \% \mathrm{La}$. These elements occur as a solid solution of goyazite-florencite mineral. Additionally, authigenic K-feldspar and kaolinite occur in this ash bed. The high concentrations of REE elements, strontium and phosphorus suggest a carbonatite source magma, but the strontium isotope ratio contradicts that origin. Such a unique composition in a volcanic ash layer is a good basis for using it as a marker horizon for correlation of sections. - Keywords: REE, goyazite, florencite, K-bentonite, Silurian, East Baltic.
\end{abstract}

\begin{abstract}
KiIPli, T., RadZievičIUS, S., Kallaste, T., KiIPli, E., SiIR, S., SoesoO, A. \& VoOlma, M. 2012. The Geniai Tuff in the southern East Baltic area - a new correlation tool near the Aeronian/Telychian stage boundary, Llandovery, Silurian. Bulletin of Geosciences 87(4), 695-704 (7 figures, 1 table). Czech Geological Survey, Prague. ISSN 1214-1119. Manuscript received August 25, 2011; accepted in revised form December 8, 2011; published online May 23, 2012; issued October 17, 2012.

Tarmo Kiipli, Toivo Kallaste, Enli Kiipli, Sven Siir, Alvar Soesso \& Margus Voolma, Institute of Geology, Tallinn University of Technology, 5 Ehitajate Road, 19086 Tallinn, Estonia; tarmo.kiipli@gi.ee, toivo.kallaste@gi.ee, alvar.soesoo@gi.ee -Sigitas Radzievičius, Department of Geology and Mineralogy, Vilnius University, M.K. Čiurlionio 21/27, LT03101 Vilnius, Lithuania, and Nature Research Centre, Institute of Geology and Geography, T. Ševčenkos 13, 03-223 Vilnius, Lithuania; sigitas.radzevicius@gf.vu.lt
\end{abstract}

Thin altered volcanic ashes (bentonites, K-bentonites) in Baltoscandian sedimentary sections, evidencing volcanism at nearby plate margins, have been found from the Upper Ordovician (Bergström et al. 1995) through lower Silurian (Bergström et al. 1992, Batchelor et al. 1995, Batchelor \& Jeppsson 1999) to the lower part of the upper Silurian (Snäll 1977). Many Silurian bentonites are recorded also in Early Palaeozoic sedimentary rocks in England (Ray 2007, 2011) and Scotland (Batchelor \& Weir 1988). In the East Baltic area ash beds from a total of 51 volcanic eruptions have been identified in the Telychian (Kiipli et al. 2008a-c, 2010b) and 50 in the Wenlock (Kiipli et al. 2010a). Ash beds in sedimentary sections carry valuable information about the geochemical type of volcanism and can be used as stratigraphical markers for precise correlation of sections.

With the aim of extending correlations of volcanic ash layers southwards, we studied two sections from Latvia, and also some remarkable bentonite interbeds from several sections in Lithuania. Laboratory analyses of these new materials revealed unusually high concentrations of REE elements, $\mathrm{Sr}$, and $\mathrm{P}$ in one of these thin volcanic ash layers.
Reporting and interpreting this find is the aim of the present article.

\section{Material and methods}

Twenty-three altered volcanic ash samples were taken from the Aeronian and lower Telychian of the Ventspils-D3 and Vidale-263 cores, Latvia (Fig. 1). In addition, nine samples were found in the same stratigraphical interval from Lithuanian cores. The thickness of the ash beds varies from $1 \mathrm{~mm}$ to $3 \mathrm{~cm}$, which is generally less than in Estonia, where ash beds frequently reach thicknesses of $5-10 \mathrm{~cm}$. The stratigraphical position of the ash beds in Lithuania was established using graptolites (Motuza et al. 2002, Paškevičius 1982). In the Aizpute-41 section the graptolite biozonation from the sedgwikii to crenulata biozones (Loydell et al. 2003) was used and correlations with the Ventspils-D3 and Vidale-263 sections were based on the lithology of sedimentary rocks and composition of sanidine in volcanic ash beds. All samples were analysed by 


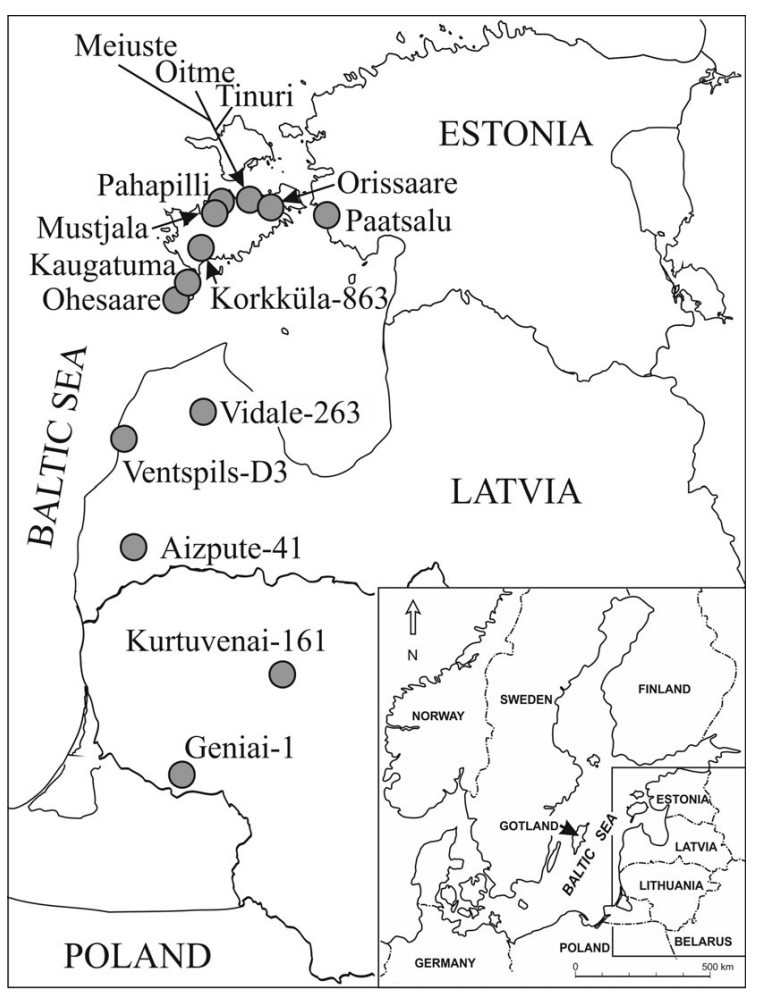

Figure 1. Location of studied drill core sections in the eastern Baltic.

X-ray diffractometry (XRD) for identifying major minerals and determination of magmatic sanidine phenocryst composition. The authors have applied the same methods in their previous works (e.g. Kiipli et al. 2010a). Samples of sufficient size (at least $8 \mathrm{~g}$ ) were subjected to standard $\mathrm{X}$-ray fluorescence (XRF) analysis for major and trace elements. Results are available in the database at the http://geokogud.info/git/reference.php?id=1586 (Kiipli et al. 2011). XRD and XRF analyses were carried out at the Institute of Geology at Tallinn University of Technology. Ten samples were analysed for trace elements by inductively coupled plasma mass spectrometry (ICP-MS) at the University of Bergen. ${ }^{87} \mathrm{Sr} /{ }^{86} \mathrm{Sr}$ ratio analyses were performed using ICP-SFMS instruments at the laboratory of ALS Scandinavia AB (see http://www.alsglobal.se for details).

\section{Results}

\section{Stratigraphy and correlations near the Aeronian/Telychian boundary in the East Baltic}

The major, upper part of the Rumba Formation in Estonia, consisting of shallow water nodular limestones, with the brachiopod Pentamerus oblongus, corals Paleofavosites obliquus and Calostylis luhai, stromatoporoid Clathrodiction variolare, gastropods Boiotremus cf. longitudinalis and Hormotoma sp. and trilobites Calymene frontosa and Encrinurus rumbaensis (Kaljo \& Einasto 1990) can now be correlated firmly with the lower part of the Telychian ranging from the Spirograptus guerichi or Spirograptus turriculatus Biozone to the Streptograptus crispus or even to the Streptograptus sartorius graptolite Biozone (Fig. 2). Formerly the Rumba Formation was correlated with the Stimulograptus sedgwickii Biozone, in the upper Aeronian (Nestor 1997). The Aeronian/Telychian boundary corresponds to the boundary of the Stimulograptus halli and Spirograptus guerichi graptolite Biozones (Loydell 2012). In sections studied by us these species were not found and therefore the position of the Aeronian/Telychian boundary is less constrained between Stimulograptus sedgwickii and Spirograptus turriculatus biozones.

The "O" volcanic tuff (ID851) - hard layer with high content of authigenic potassium feldspar, having uniquely the most potassic composition of the volcanic sanidine ( $21.1 \pm 0.4 \mathrm{~mol} \%$ of the $\mathrm{Na}+\mathrm{Ca}$ component) among Silurian volcanic ashes, forms a perfect marker horizon in the upper part of the Rumba Formation in Estonia (Kiipli et al. 2006). Biotite in the "O" Tuff is magnesium-rich (Kiipli et al. 2008c). In the Silurian deep shelf area in Latvia and Lithuania the "O" Bentonite (kaolinite and illite-smectite rich variety of the same eruption layer) occurs 4.6-5.9 m above the organic rich shales of the Dobele Formation with Stimulograptus sedgwickii in the upper part. In the Aizpute-41 core 10-15 cm below the "O" Bentonite Spirograptus turriculatus has been found (Loydell et al. 2003). The "O" Tuff in Estonia has been correlated with the Osmundsberg K-bentonite (illite-smectite rich variety of the same eruption layer) in Scandinavia (Bergström et al. 1998, Inanli et al. 2009). In the Osmundsberget section in Sweden, Loydell \& Maletz (2002) identified Spirograptus turriculatus both below and above the Osmundsberg K-bentonite.

Study of Lithuanian and Latvian cores has revealed in the interval, barren of graptolites, between the St. sedgwickii and Sp. turriculatus biozones a new, thin $(0.7-1.0 \mathrm{~cm})$ volcanic tuff layer with a unique chemical and mineralogical composition. This layer contains up to $12 \%$ phosphorus $6 \% \mathrm{Ce}, 3 \% \mathrm{La}$ and $11 \% \mathrm{Sr}$ (Fig. 3). We propose the name Geniai Tuff (tuff, because all known occurrences are represented by hard layers consisting dominantly of goyazite-florencite and potassium feldspar with subordinate clay) and assign the ID number 890 to this layer. The Geniai Tuff has been found in the Geniai-1 core at a depth of $1752.1 \mathrm{~m}$, in the Ventspils-D3 core at $848.5 \mathrm{~m}$ and in the Vidale-263 core at $754.4 \mathrm{~m}$ (Fig. 2). In the Geniai-1 core this layer occurs 1.1-2.7 m above the Aeronian/Telychian boundary. The Aeronian/Telychian boundary corresponds to the upper boundary of the St. sedgwickii Biozone in Lithuania (Paškevičius 1982). Stimulograptus halli, index species of the uppermost Aeronian graptolite 


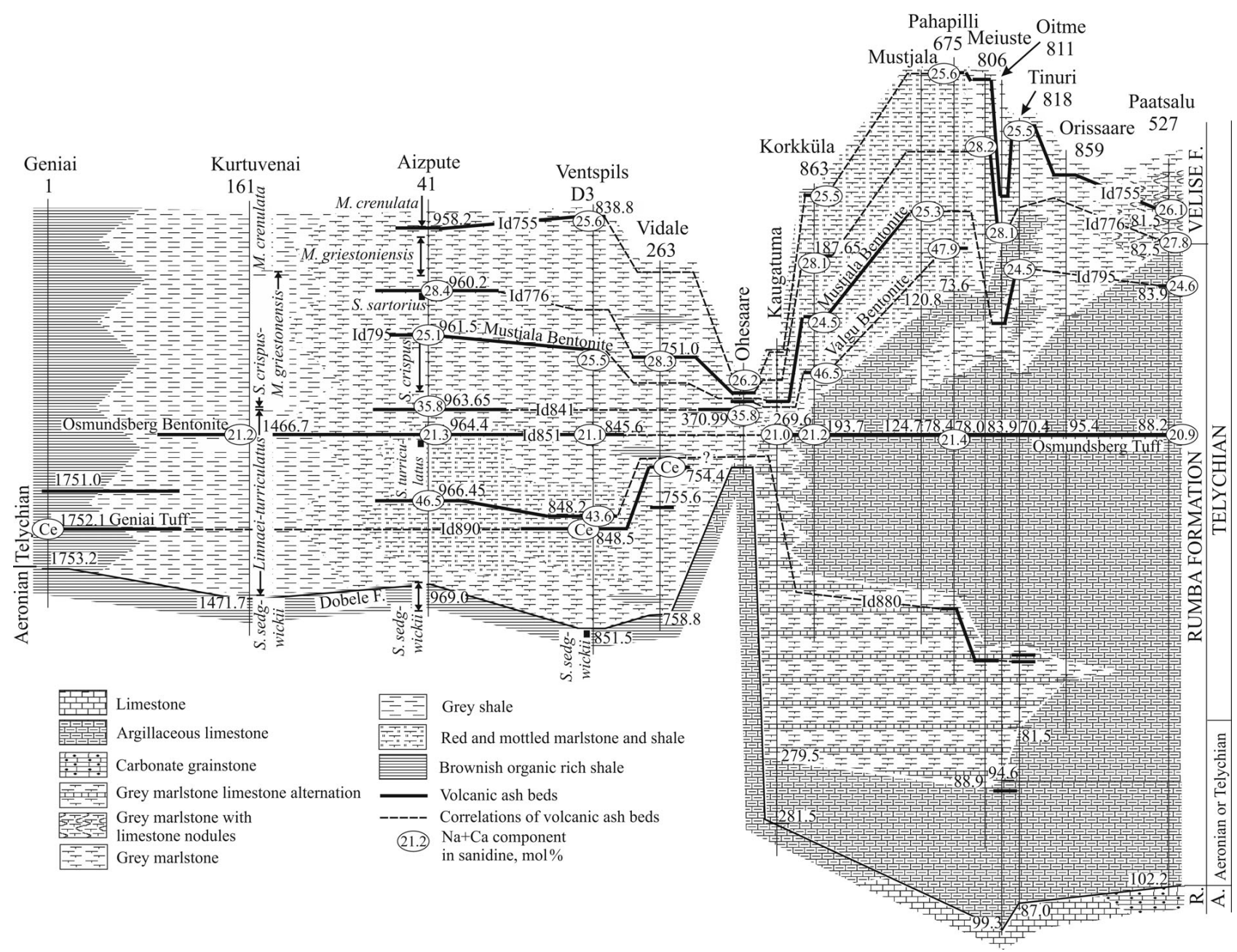

Figure 2. Stratigraphical position of the Geniai Tuff. Correlation of altered volcanic ashes is based on the sanidine phenocryst composition. The Geniai Tuff is marked by Ce (cerium). Numbers near the drill cores represent depths in metres. Graptolite biozonation of the Aizpute core is from Loydell et al. (2003).

biozone according to Loydell (2012), was not found in Lithuania. Alike St. sedgwickii was not found in the Geniai-1 drill core. The upper boundary of the St. sedgwickii biozone is indicated by the last appearance of Metaclimacograptus hughesi at a depth of $1754.8 \mathrm{~m}$ in Geniai-1. The first graptolite assemblage of the $R$. linnaei and $S p$. turriculatus biozones was found at a depth of $1753.2 \mathrm{~m}$ in Geniai-1. The assemblage comprises Monograptus marri and Streptograptus nodifer. Monograptus marri occurs in the $R$. linnaei and Sp. turriculatus biozones in Lithuania (Paškevičius 1997) and in Bohemia (Štorch \& Kraft 2009). The interval from $1754.8 \mathrm{~m}$ to $1753.2 \mathrm{~m}$ is without graptolites or the graptolite rhabdosomes are too badly preserved for identification. The distribution of the Geniai Tuff, spanning over $270 \mathrm{~km}$ from South to North, is shown on Fig. 3.

Unfortunately, we have not found the Geniai Tuff in the Rumba Formation in Estonia. The lower part of the Rumba Formation includes three thin feldspathic tuff lay- ers, but none of these contains elevated REE, phosphorus and strontium content. Probably one of these geochemically very similar layers, characterized by the lowest $\mathrm{Zr} / \mathrm{TiO}_{2}$ ratios (0.01-0.03) among Telychian bentonites, correlates with an ash in the Ventspils-D3 core at a depth of $848.2 \mathrm{~m}\left(\mathrm{Zr} / \mathrm{TiO}_{2}=0.019\right), 30 \mathrm{~cm}$ above the Geniai Tuff. $\mathrm{Zr} / \mathrm{Th}$ ratios varying between 10 and 15 suggest correlation of Ventspils-D3 $848.2 \mathrm{~m}$ with ash bed ID880 in Estonia. Another two ashes in Estonia revealed slightly higher $\mathrm{Zr} / \mathrm{Th}$ ratios, varying between 20 and 25 (http://geokogud.info/git/reference.php?id=1586 record numbers 134-139, 251-252, 471-472, 790, 1157). These correlations constrain the position of the Aeronian/Telychian boundary not higher than within the lower $5 \mathrm{~m}$ of the Rumba Formation in Estonia.

The upper boundary of the Rumba Formation is often sharp, between argillaceous limestones and marlstones, but in some sections a transitional interval occurs including alternating limestones and marlstones. In the palaeon- 


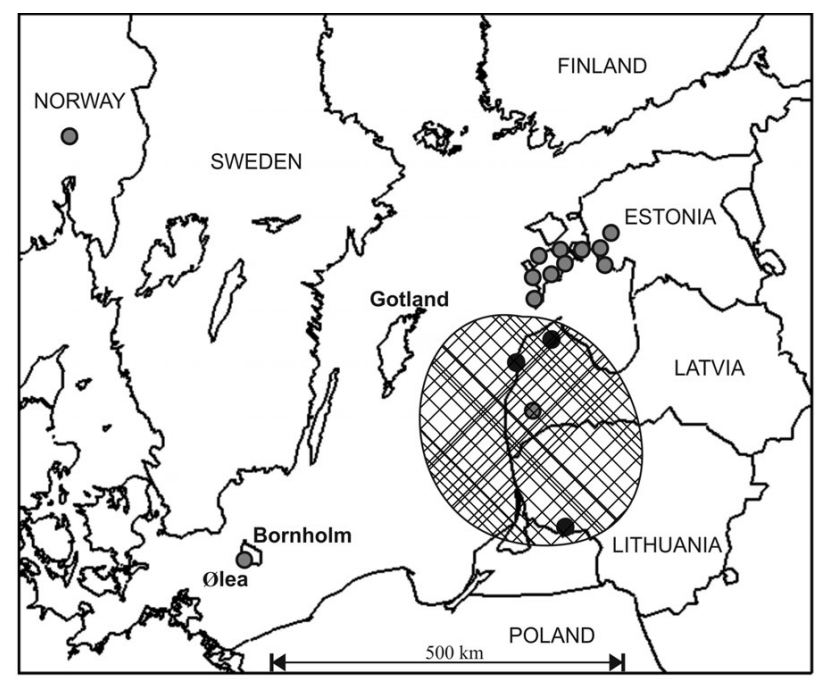

- Localities, where anomalous volcanic ash bed containing high concentrations of $\mathrm{P}, \mathrm{La}, \mathrm{Ce}, \mathrm{Sr}$ has been found

- Localities, where Aeronian/Telychian boundary interval was carefully studied, but anomalous volcanic ash was not found Distribution area of the Geniai Tuff

Figure 3. Known distribution area of the Geniai Tuff.

tologically well studied Paatsalu section (Hints et al. 2006) the transition interval is represented by the occurrence of common limestone nodules in the marlstones of the Velise Formation. The Mustjala Bentonite (ID795) has been found in the upper part of the Rumba Formation in the Paatsalu core, while in the Tinuri and Oitme cores it occurs in the transition interval and in the western part of Saaremaa in the Mustjala, Korkküla and Kaugatuma cores it occurs in marlstones of the Velise Formation. Therefore the upper boundary of the Rumba Formation is clearly diachronous over a few tens of kilometres in Estonia: red marlstones of the Velise Formation in the western part of Saaremaa correlate with grey nodular limestones of the upper part of the Rumba Formation on the mainland of Estonia. In the Aizpute-41 core the Mustjala Bentonite was identified in the upper part of the S. crispus graptolite Biozone.

\section{Major minerals in altered volcanic ashes}

While ash beds in Estonia are composed mainly of illitesmectite and authigenic potassium feldspar (Kiipli et al. 2008b), with kaolinite present only in sections near the southern border, in Latvia and Lithuania kaolinite is a common major component besides illite-smectite, whereas $\mathrm{K}$-feldspar is rare. This areal difference has been studied in the Ordovician Kinnekulle ash bed (Kiipli et al. 2007) and originates probably from the differences in sedimentary facies. During Palaeozoic times Latvia and Lithuania were

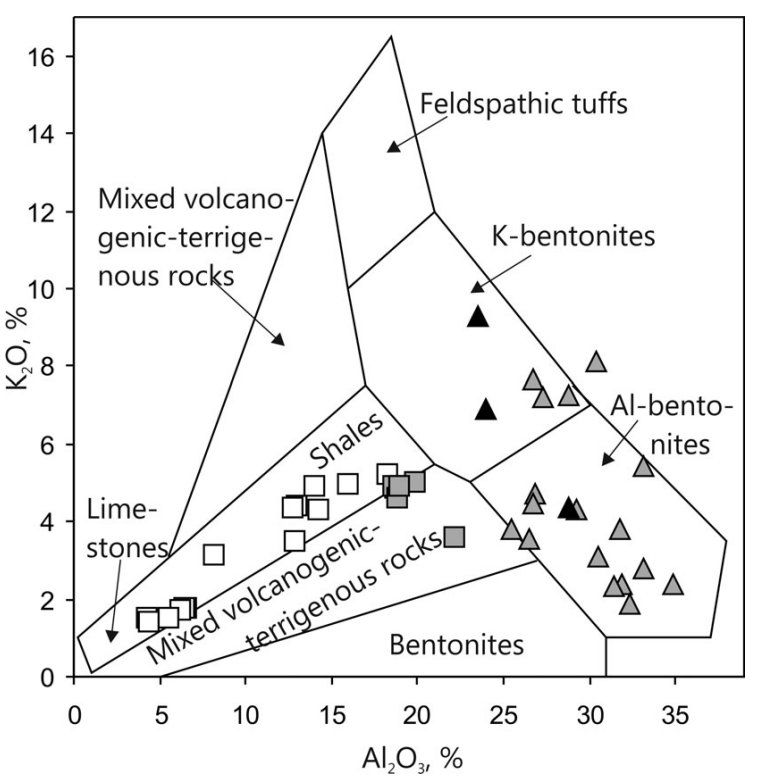

Figure 4. $\mathrm{Al}_{2} \mathrm{O}_{3}$ and $\mathrm{K}_{2} \mathrm{O}$ contents of studied samples. Grey triangles Al-bentonites and K-bentonites from Latvia and Lithuania. Black triangles - altered volcanic ash beds containing goyazite-florencite. Empty quadrangles - terrigenous shales and marlstones from Latvia. Grey quadrangles - mixed volcanogenic-terrigenous samples. Field boundaries of rock types are from Kiipli et al. (2010a).

located in the deep shelf and Estonia mainly in the shallow shelf area. Hints et al. (2008), however, proposed a late diagenetic origin for potassium feldspar in bentonites. Fig. 4 shows this compositional variation in terms of $\mathrm{Al}_{2} \mathrm{O}_{3}$ and $\mathrm{K}_{2} \mathrm{O}$ content.

Three samples of the Geniai Tuff reveal unusual reflections on XRD patterns indicating goyazite-florencite ( $\mathrm{Sr}, \mathrm{Ce}, \mathrm{La}, \mathrm{Al}$ phosphate) solid solution as one of the major minerals. This mineral occurs as rare grains in Silurian volcanic ashes in the East-Baltic, but as a major component it has not been found previously. Authigenic K-feldspar and kaolinite associate with goyazite-florencite. In some other ash beds apatite is a significant constituent, reaching several percent. A study of the Geniai Tuff by EDS microanalysis showed that concentrations of anomalous elements within the bed form two cycles reaching extremely high values in millimetre-scale horizontal lenses: up to $12 \% \mathrm{P}$ and $\mathrm{Sr}$, up to $6 \%$ of $\mathrm{Ce}$ and $3 \%$ of $\mathrm{La}$ (Fig. 5). These concentrations indicate that the thin lenses within the Geniai Tuff consist almost entirely of the mineral goyazite-florencite. Sharp contacts with the host shale and the content of authigenic K-feldspar and kaolinite together with the absence of terrigenous quartz typical of the numerous volcanic ash beds and not the terrigenous shales in the southern East Baltic demonstrate the volcanic origin of the Geniai Tuff. Further evidence for the volcanic origin comes from the unusually high concentration (2.3-3.0\%) of immobile $\mathrm{TiO}_{2}$. In contrast, the concentration of $\mathrm{TiO}_{2}$ in carbonate-free host shales in the East Bal- 


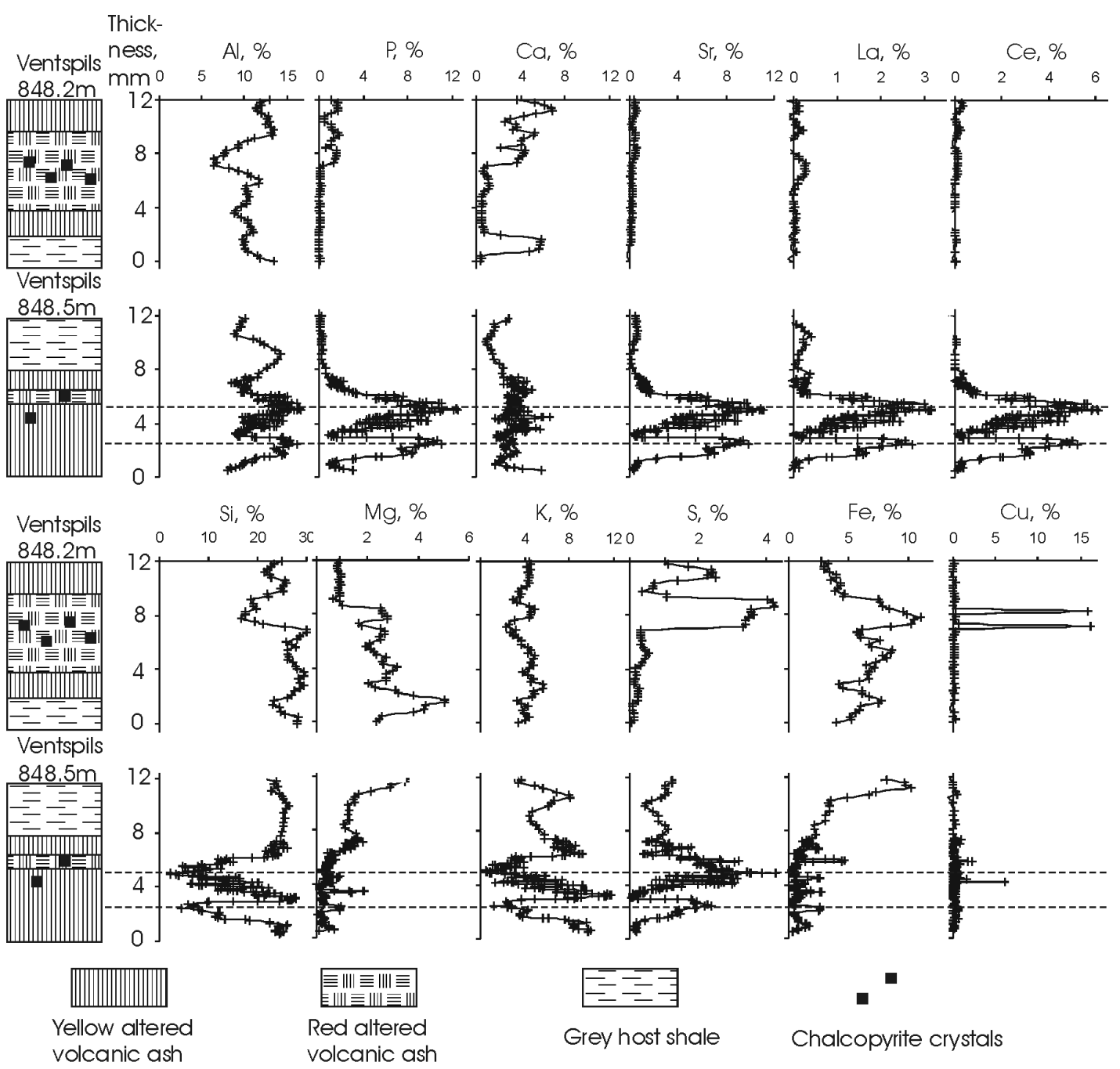

Figure 5. Distribution of chemical elements within two thin lower Telychian ash beds. Ventspils $848.5 \mathrm{~m}$ is the Geniai Tuff. The Geniai Tuff is characterised by very high contents of REE, Sr and P. Ash bed only $30 \mathrm{~cm}$ higher in a section do not contain any high concentrations of these elements. This indicates, that REE, $\mathrm{Sr}$ and $\mathrm{P}$ in the Geniai Tuff originated from the volcanic ash of specific composition and not from the diagenetic processes.

tic is very stable, ranging between $0.7-0.9 \%$ (Kiipli et al. 2008b).

Red patches in the host rock and also in the Geniai Tuff in the Ventspils core indicate an oxic sedimentary environment (Kiipli et al. 2000a). Silurian red sedimentary rocks and volcanic ashes in the East Baltic often contain early diagenetic chalcopyrite (Kiipli et al. 2000b). The same has been found also in the Geniai Tuff and other ash beds in the Ventspils core (Fig. 5). The Geniai Tuff in the Geniai and Vidale cores formed in anoxic sediments, indicated by the grey colour of rocks caused by the occurrence of dispersed pyrite.

\section{Composition of the goyazite-florencite}

According to the XRF and ICP-MS analyses, aluminous phosphate in the Geniai Tuff of the Geniai-1 core, depth
$1752.1 \mathrm{~m}$, contains $61 \%$ goyazite $\mathrm{SrAl}_{3}\left(\mathrm{PO}_{4}\right)_{2}(\mathrm{OH})_{5} \times\left(\mathrm{H}_{2} \mathrm{O}\right)$ and $39 \%$ florencite $($ REE $) \mathrm{Al}_{3}\left(\mathrm{PO}_{4}\right)_{2}(\mathrm{OH})_{6}$ component in a solid solution (Table 1). Unit cell dimensions (trigonal $\mathrm{a}=6.986 \AA$ and $\mathrm{c}=16.418 \AA$ ) calculated from XRD reflections are in good accordance with such a composition. Composition of the aluminous phosphate in the Ventspils and Vidale cores is similar. In total, composition of the goyazite-florencite in the Geniai Tuff varies between $57-65 \%$ of the goyazite component and correspondingly $35-43 \%$ of the florencite component. A small (7-14\%) crandallite $\mathrm{CaAl}_{3}\left(\mathrm{PO}_{4}\right)_{2}(\mathrm{OH})_{5} \times\left(\mathrm{H}_{2} \mathrm{O}\right)$ component is also possible, although cannot be proved by geochemical data because XRD reflections indicate the presence of some apatite; therefore some $\mathrm{CaO}$ and $\mathrm{P}_{2} \mathrm{O}_{5}$ certainly belong to this mineral.

In the florencite component $\mathrm{Ce}, \mathrm{La}$ and $\mathrm{Nd}$ comprise about $88 \%$ of the total REE content and the remaining $12 \%$ is formed by Pr and heavier REE. 
Table 1. Major and trace elements in the Geniai Tuff and other volcanic ash beds.

\begin{tabular}{|c|c|c|c|c|c|c|c|}
\hline \multirow{2}{*}{\multicolumn{2}{|c|}{$\begin{array}{l}\text { Core } \\
\text { Depth, m }\end{array}$}} & \multicolumn{3}{|c|}{ Ventspils-D3 } & \multirow{2}{*}{$\begin{array}{c}\text { Vidale-263 } \\
754.4\end{array}$} & \multirow{2}{*}{$\begin{array}{r}\text { Geniai-1 } \\
1752.1\end{array}$} & \multirow{2}{*}{$\begin{array}{r}\text { Geniai-1 } \\
1751.0\end{array}$} \\
\hline & & 845.6 & 848.2 & 848.5 & & & \\
\hline ID & & 851 & 880 & 890 & 890 & 890 & 860 \\
\hline \multicolumn{8}{|c|}{ XRF analyses } \\
\hline $\mathrm{SiO}_{2}$ & $\%$ & 51.0 & 46.9 & 43.2 & 49.6 & 38.7 & 49.7 \\
\hline $\mathrm{TiO}_{2}$ & $\%$ & 0.36 & 1.63 & 2.32 & 2.40 & 2.97 & 3.08 \\
\hline $\mathrm{Al}_{2} \mathrm{O}_{3}$ & $\%$ & 26.9 & 23.8 & 23.9 & 23.2 & 28.4 & 27.3 \\
\hline $\mathrm{Fe}_{2} \mathrm{O}_{3} \mathrm{~T}$ & $\%$ & 5.55 & 4.48 & 1.49 & 1.34 & 0.52 & 2.65 \\
\hline $\mathrm{MnO}$ & $\%$ & 0.016 & 0.009 & 0.008 & 0.007 & 0.003 & 0.006 \\
\hline $\mathrm{MgO}$ & $\%$ & 2.20 & 1.47 & 0.65 & 0.66 & 0.45 & 0.6 \\
\hline $\mathrm{CaO}$ & $\%$ & 0.41 & 4.59 & 3.32 & 1.54 & 1.49 & 1.63 \\
\hline $\mathrm{K}_{2} \mathrm{O}$ & $\%$ & 4.70 & 5.46 & 7.20 & 9.62 & 4.33 & 7.2 \\
\hline $\mathrm{Na}_{2} \mathrm{O}$ & $\%$ & 1.1 & 1.4 & 0.6 & 0.6 & $<0.1$ & $<0.1$ \\
\hline $\mathrm{P}_{2} \mathrm{O}_{5}$ & $\%$ & 0.052 & 2.92 & 5.10 & 3.12 & 7.86 & 1.05 \\
\hline $\mathrm{S}$ & $\%$ & 0.06 & 0.30 & 0.27 & 0.58 & 0.50 & 0.56 \\
\hline $\mathrm{Cl}$ & $\%$ & 0.36 & 0.71 & 0.27 & 0.09 & 0.04 & 0.020 \\
\hline LOI & $\%$ & 7.0 & 6.8 & 6.4 & 5.0 & 9.2 & 6.6 \\
\hline $\mathrm{Ce}$ & $\%$ & $<0.006$ & 0.04 & 0.72 & 0.36 & 1.19 & 0.06 \\
\hline $\mathrm{La}$ & $\%$ & $<0.004$ & 0.01 & 0.36 & 0.23 & 0.47 & 0.03 \\
\hline $\mathrm{Sr}$ & $\%$ & 0.01 & 0.02 & 1.17 & 0.87 & 2.59 & 0.06 \\
\hline As & ppm & 5 & 3 & 5 & 12 & 2 & 15 \\
\hline $\mathrm{Ba}$ & ppm & 280 & 393 & 528 & 675 & 482 & 357 \\
\hline $\mathrm{Br}$ & ppm & 17 & 29 & 10 & 4 & 0 & 4 \\
\hline $\mathrm{Cr}$ & ppm & 8 & 6 & 32 & 25 & 39 & 14 \\
\hline $\mathrm{Cu}$ & ppm & 481 & 1,907 & 783 & 418 & 90 & 446 \\
\hline $\mathrm{Ga}$ & ppm & 21 & 11 & 4 & 6 & 5 & 10 \\
\hline $\mathrm{Nb}$ & ppm & 14 & 19 & 38 & 13 & 15 & 24 \\
\hline $\mathrm{Ni}$ & ppm & 11 & 86 & 8 & 24 & 16 & 10 \\
\hline $\mathrm{Pb}$ & ppm & 4 & 27 & 23 & 24 & 4 & 3 \\
\hline V & ppm & 14 & 123 & 116 & 198 & 279 & 331 \\
\hline $\mathrm{Y}$ & ppm & -1 & 393 & 356 & 77 & 77 & 108 \\
\hline $\mathrm{Zn}$ & ppm & 25 & 15 & 11 & 11 & 18 & 14 \\
\hline
\end{tabular}

Trace element geochemistry of the altered volcanic ash layers: distinguishing the Geniai Tuff from other lithologies and volcanic ashes

According to the shale-normalised REE patterns (Fig. 6) the analysed samples are divided into four groups:

1. The host terrigenous shale from Ventspils $846.0 \mathrm{~m}$. REEs form a flat pattern very similar to the average Post-Archean Australian Shale (PAAS) (McLennan 1989).

2. The Osmundsberg Bentonite from Ventspils $845.6 \mathrm{~m}$ reveals very low concentrations of $R E E$ showing also a flat pattern. A specific feature is a significant positive $\mathrm{Eu}$ anomaly evidencing source magma generation through preferential melting of feldspars (Rollinson 1993).

3 . Volcanic ash beds with moderately elevated concentrations of REE, e.g. Geniai $1751.00 \mathrm{~m}$, Aizpute $966.45 \mathrm{~m}$, Ventspils $848.20 \mathrm{~m}$, and Vidale $755.60 \mathrm{~m}$. Concentrations of Ce vary between 300 and $600 \mathrm{ppm}$. These layers contain a few percent of $\mathrm{P}_{2} \mathrm{O}_{5}$ and XRD indicates the presence of apatite. Shale-normalised REE patterns show enrichment in middle $R E E$, forming so-called "hat"-like patterns.

4. The Geniai Tuff with high concentrations of REE, e.g. Geniai $1752.1 \mathrm{~m}$, Ventspils $848.5 \mathrm{~m}$ and Vidale $754.4 \mathrm{~m}$. The Ce content varies between 0.4 and $1.3 \%$. These layers contain goyazite-florencite as a main carrier of REE. REE patterns show strong enrichment of light REE and a distinct positive Er anomaly.

\section{Discussion}

\section{Mineralogy and geochemistry of the Geniai Tuff}

Goyazite-florencite (grandallite mineral group) solid solution minerals, $(\mathrm{Sr}, \mathrm{Ce}, \mathrm{Nd}, \mathrm{La}) \mathrm{Al}_{3}\left(\mathrm{PO}_{4}\right)_{2}(\mathrm{OH})_{6}$, have been 
Table 1 - continued

\begin{tabular}{|c|c|c|c|c|c|c|c|}
\hline \multirow{2}{*}{\multicolumn{2}{|c|}{$\begin{array}{l}\text { Core } \\
\text { Depth, m }\end{array}$}} & \multicolumn{3}{|c|}{ Ventspils-D3 } & \multirow{2}{*}{$\begin{array}{c}\text { Vidale-263 } \\
754.4\end{array}$} & \multirow{2}{*}{$\begin{array}{r}\text { Geniai-1 } \\
1752.1 \\
\end{array}$} & \multirow{2}{*}{$\begin{array}{r}\text { Geniai-1 } \\
1751.0 \\
\end{array}$} \\
\hline & & 845.6 & 848.2 & 848.5 & & & \\
\hline ID & & 851 & 880 & 890 & 890 & 890 & 860 \\
\hline \multicolumn{8}{|c|}{ ICP-MS analyses } \\
\hline $\mathrm{Ba}$ & ppm & 349 & 413 & 565 & 854 & 481 & 416 \\
\hline Co & ppm & 5.1 & 24.6 & 2.8 & 8.4 & 4.0 & 3.9 \\
\hline Cs & ppm & 14.1 & 2.7 & 0.5 & 1.1 & 1.5 & 1.6 \\
\hline $\mathrm{Cu}$ & ppm & 711 & 4,022 & 1,146 & 312 & 107 & 446 \\
\hline Hf & ppm & 5.0 & 8.6 & 6.2 & 8.4 & 9.1 & 9.3 \\
\hline Mn & ppm & 111 & 69 & 70 & 89 & 29 & 53 \\
\hline $\mathrm{Pb}$ & ppm & 6.0 & 24.5 & 29.7 & 37.4 & 7.0 & 13.6 \\
\hline $\mathrm{Sc}$ & ppm & 7.9 & 20.5 & 17.6 & 13.2 & 13.4 & 12.7 \\
\hline $\mathrm{Sr}$ & ppm & 112 & 259 & 12,821 & 9,612 & 29,913 & 668 \\
\hline $\mathrm{Th}$ & ppm & 37.5 & 21.0 & 18.8 & 30.6 & 30.0 & 24.1 \\
\hline $\mathrm{Ti}$ & ppm & 2,476 & 12,121 & 17,259 & 14,792 & 21,904 & 22,658 \\
\hline $\mathrm{U}$ & ppm & 0.9 & 8.4 & 15.9 & 42.8 & 34.8 & 40.9 \\
\hline V & ppm & 27 & 123 & 124 & 161 & 278 & 268 \\
\hline $\mathrm{Y}$ & ppm & 2.6 & 364 & 372 & 93 & 138 & 100 \\
\hline $\mathrm{Zr}$ & ppm & 142 & 332 & 255 & 384 & 406 & 385 \\
\hline $\mathrm{La}$ & ppm & 3.7 & 175 & 4,121 & 2,782 & 5,452 & 194 \\
\hline $\mathrm{Ce}$ & ppm & 10.3 & 606 & 8,161 & 4,229 & 13,546 & 431 \\
\hline $\operatorname{Pr}$ & ppm & 1.0 & 66 & 508 & 312 & 1,629 & 52 \\
\hline $\mathrm{Nd}$ & ppm & 4.3 & 374 & 1,579 & 973 & 7,641 & 254 \\
\hline $\mathrm{Sm}$ & ppm & 0.8 & 95.1 & 157.4 & 110.6 & 906.2 & 62.4 \\
\hline $\mathrm{Eu}$ & ppm & 0.3 & 24.6 & 31.7 & 24.7 & 118.7 & 15.1 \\
\hline $\mathrm{Gd}$ & ppm & 0.8 & 100.1 & 176.1 & 114.7 & 731.7 & 52.8 \\
\hline $\mathrm{Tb}$ & ppm & 0.1 & 16.1 & 29.0 & 16.6 & 104.7 & 8.0 \\
\hline Dy & ppm & 0.7 & 78.8 & 82.9 & 31.9 & 54.9 & 31.4 \\
\hline Но & ppm & 0.1 & 14.5 & 15.4 & 4.8 & 7.5 & 5.1 \\
\hline $\mathrm{Er}$ & ppm & 0.4 & 39.2 & 56.7 & 24.8 & 142.8 & 14.1 \\
\hline $\mathrm{Tm}$ & ppm & 0.1 & 4.5 & 4.6 & 1.3 & 1.7 & 1.4 \\
\hline $\mathrm{Yb}$ & ppm & 0.4 & 29.0 & 28.9 & 9.8 & 19.0 & 9.9 \\
\hline $\mathrm{Lu}$ & ppm & 0.1 & 3.8 & 3.8 & 1.1 & 1.6 & 1.2 \\
\hline
\end{tabular}

found in sedimentary rocks as early diagenetic trace minerals in Australia (Rasmussen 1996). In other works florencite has been interpreted as a hydrothermal alteration product (Lefebvre \& Gasparrini 1980), as metamorphic, associated with monazite (Nagy et al. 2002), and as a weathering product of apatite and monazite in alkaline carbonatites from Brazil (Ribeiro et al. 2005). Grandallite has been found also in kaolinite-rich altered volcanic ash layers in coal formations (Rao \& Walsh 1997, Ward 2002).

In the East-Baltic volcanic ash layers goyazite-florencite could originate in the volcanic ash only through submarine weathering (halmirolysis) of volcanic ash on the seabed and/or early diagenetic processes in sediments. The sedimentary rocks in the East Baltic are not metamorphosed and have not been subjected to hydrothermal alteration. Our samples were taken from deep drill-cores - consequently the rocks had not been subjected to subaerial weathering in ex- posures. The most critical prerequisite for formation of goyazite-florencite is the availability of major elements of this mineral, most of which are characterized by low solubility in Earth surface environments and cannot migrate for long distances. Reactive $\mathrm{Al}$ is always available in abundance in dissolving and crystallizing amorphous volcanic ashes. Commonly this process results in the formation of Al-rich clay minerals. This is the case also in many ash layers close to the Geniai Tuff in core, often lying only $0.3-1.5$ m vertically separate from it. This leads to the conclusion that $\mathrm{Sr}$, $R E E$ and $\mathrm{P}$ were incorporated into goyazite-florencite from the specific volcanic material with a high content of these elements, and not from the sedimentary environment.

Comparing $\mathrm{Zr} / \mathrm{TiO}_{2}$ and $\mathrm{Ce} / \mathrm{Al}_{2} \mathrm{O}_{3}$ ratios from Geniai Tuff with common silicate volcanic rocks and carbonatites reveals a similarity with carbonatites (Fig. 7). The ${ }^{87} \mathrm{Sr} /{ }^{86} \mathrm{Sr}$ isotope ratio determined in a sample of the Geniai Tuff 


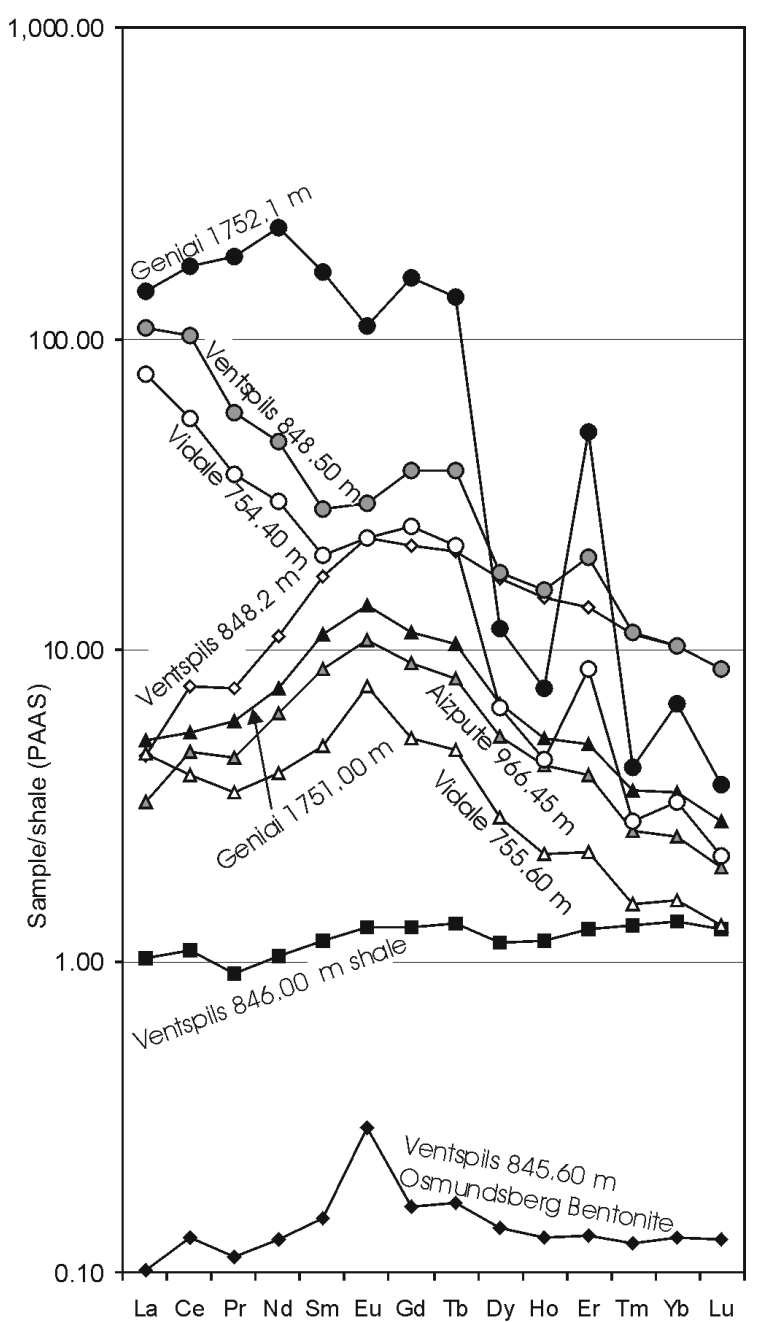

Figure 6. REE element patterns of altered volcanic ashes from the Aeronian/Telychian boundary interval. REE contents are normalised relative to the Post-Archean Australian Shale (PAAS). Geniai $1752.1 \mathrm{~m}$, Ventspils $848.5 \mathrm{~m}$ and Vidale $754.4 \mathrm{~m}$ represent the Geniai Tuff.

from Ventspils core, depth $848.5 \mathrm{~m}$ is $0.70891 \pm 0.00002$. This value differs significantly from the late Llandovery seawater value (Brand et al. 2006). The absence of a negative Ce anomaly on shale-normalised REE patterns (Fig. 6) characteristic of oxic seawater (Shields \& Stille 2001) also indicates a source other than marine ${ }^{87} \mathrm{Sr} /{ }^{86} \mathrm{Sr}$ in the Geniai Tuff differs even more significantly from most mantle values, excluding $\mathrm{Sr}$ derivation from common sources in the mantle as well. High ${ }^{87} \mathrm{Sr} /{ }^{86} \mathrm{Sr}$ values are typical for the continental crust and only rarely occur in the mantle. In these cases, it is possible that continental crust has been subducted (Rollinson 1993).

High concentrations of REE and phosphorus in magmatic rocks are commonly associated with alkaline carbonatite intrusions (Hoernle et al. 2002, Ribeiro et al. 2005). The problem is that almost all carbonatites originated from a deep mantle source with low values of ${ }^{87} \mathrm{Sr} /{ }^{86} \mathrm{Sr}$ (Bell $\&$ Simonetti 2010). Therefore the geochemical type of the

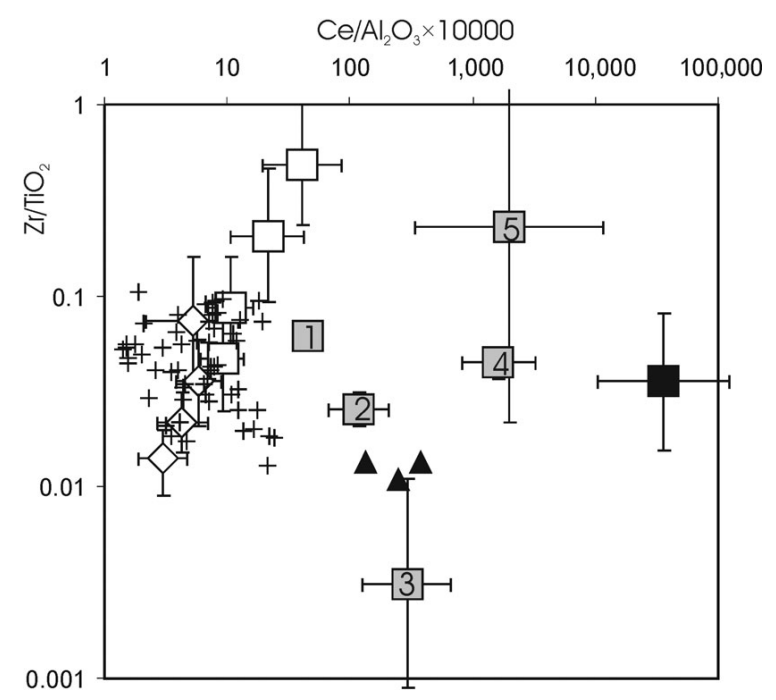

Figure 7. Immobile element $\mathrm{Zr} / \mathrm{TiO}_{2}$ and $\mathrm{Ce} / \mathrm{Al}_{2} \mathrm{O}_{3}$ ratios in the Telychian ash beds of the eastern Baltic. Crosses - Telychian bentonites from Estonia. Black triangles - Geniai Tuff. Empty rhombs with error bars (one standard deviation) - Italian subalkaline volcanic rocks and empty quadrangles with error bars - alkaline volcanic rocks (data from Peccerillo 2005). Grey quadrangles - some carbonatites of the world: 1 - Italy, 2 - Uganda, 3 - China, 4 - Cape Verde extrusive, 5 - Cape Verde intrusive (Peccerillo 2005, Mourão et al. 2010, Nelson Eby et al. 2009, Xu et al. 2008). Black quadrangle - Ol Donio Lengai natro-carbonatite (Zaitsev \& Keller 2006). Chart shows extreme compositional variation of carbonatites, exceeding significantly the variation in silicate rocks and shows the Geniai Tuff falling into the field of carbonatites.

magmatic source of the Geniai Tuff cannot be demonstrated conclusively and remains under discussion.

\section{Possible mechanism for increasing element concentration in a sedimentary environment}

Although the possible source for the Geniai Tuff - a carbonatite magma - contains high concentrations of REE compared with rocks common in the Earth's crust, concentrations reaching as high as several percent are not common. Therefore we propose that the majority of the carbonate portion of the carbonatite source magma was dissolved and removed in the marine environment. As a result, components characterized by lower solubility were concentrated strongly in a residue that forms the thin tuff layer.

\section{Time of the anomalous high-REE event}

According to the correlation with the established graptolite zonation, an anomalous magmatic REE event occurred close to the Aeronian/Telychian boundary, with ash beds being found in the lowermost layers of the Telychian. The Aeronian/Telychian boundary is currently dated at $436 \pm$ $1.9 \mathrm{Ma}$ (Ogg 2004). The Osmundsberg K-bentonite, lying 
directly above the anomalous volcanic layer within Spirograptus turriculatus Biozone, was dated from zircons as $438.7 \pm 1.0 \mathrm{Ma}$ using the ${ }^{207} \mathrm{~Pb} /{ }^{235} \mathrm{U}$ method (Bergström et al. 2008). These dates suggest that the anomalous magmatic REE event occurred at approximately $438 \mathrm{Ma}$.

\section{Conclusions}

Considering all of the geochemical and mineralogical data, we propose that the Geniai Tuff originated from a volcanic eruption $c a 438 \mathrm{Ma}$. The high content of REE, Sr and $\mathrm{P}$ suggest a carbonatite source magma, but the strontium isotope ratio contradicts this. So the source magma type of the Geniai Tuff remains under discussion. Dissolution of supposed major carbonate material in the sedimentary environment may have caused extreme residual enrichment of immobile elements in the ash bed. A volcanic ash bed of such an anomalous composition forms a perfect marker horizon for stratigraphy.

\section{Acknowledgements}

We thank A. Murnieks, R. Pomeranceva (Latvian Agency of Environment, Meteorology and Geology) for assistance with the study of drill cores, V. Motuza (Vilnius University) for providing volcanic ash samples from Lithuania, A.R. Woolley (Natural History Museum London) for useful advice, J. Kosler (Bergen University) for ICP-MS analyses and the late K. Orlova (Tallinn University of Technology) for XRF analyses. S. Peetermann and D. Loydell helped to improve the English. Questions and comments of reviewers W. Huff and D. Ray helped to improve the manuscript. This study is a contribution to IGCP 591, Estonian Science Foundation grants 8963 and 7605, and target financing project SF0140016s09. S. Radzevičius thanks the Science Council of Lithuania MIP-034/2012.

\section{References}

BATCHELOR, R.A. \& JEPPSSON, L. 1999. Wenlock metabentonites from Gotland, Sweden: geochemistry, sources and potential as chemostratigraphic markers. Geological Magazine 136, 661-669. DOI 10.1017/S001675689900285X

BATCHELOR, R.A. \& WEIR, J.A. 1988. Metabentonite geochemistry: magmatic cycles and graptolite extinctions at Dob's Linn, southern Scotland. Transactions of the Royal Society of Edinburgh, Earth Sciences 79, 19-41.

BATCHELOR, R.A., WeIR, J.A. \& SPJELDNÆS, N. 1995. Geochemistry of Telychian metabentonites from Vik, Ringerike District, Oslo region. Norsk Geologisk Tidsskrift 75, 219-228.

BELL, K. \& SimONETTI, A. 2010. Source of parental melts to carbonatites - critical isotopic constraints. Mineralogy and Petrology 98, 77-89. DOI 10.1007/s00710-009-0059-0

BergströM, S.M., HufF, W.D. \& Kolata, D.R. 1998. The Lower Silurian Osmundsberg K-bentonite. Part I: strati- graphic position, distribution, and palaeogeographic significance. Geological Magazine 135, 1-13.

DOI 10.1017/S0016756897007887

BERGSTRÖM, S.M., HufF, W.D., Kolata, D.R. \& BAUERT, H. 1995. Nomenclature, stratigraphy, chemical fingerprinting and areal distribution of some Middle Ordovician K-bentonites in Baltoscandia. GFF 117, 1-13.

Bergström, S.M., HufF, W.D., Kolata, D.R. \& Kaljo, D. 1992. Silurian K-bentonites in the Iapetus Region: A preliminary event-stratigraphic and tectonomagmatic assessment. GFF 114, 327-334.

BergströM, S.M., TOPRAK, F.Ö., HufF, W.D. \& Mundil, R. 2008. Implications of a new, biostratigraphically well-controlled, radio-isotopic age for the lower Telychian Stage of the Llandovery Series (Lower Silurian, Sweden). Episodes 31, 309-314.

BRAND, U., AZMY, K. \& VEIZER, J. 2006. Evaluation of the Salinic I tectonic Cancaniri glacial and Ireviken biotic events: Biochemostratigraphy of the Lower Silurian succession in the Niagara Gorge area, Canada and U.S.A. Palaeogeography, Palaeoclimatology, Palaeoecology 241, 192-213. DOI 10.1016/j.palaeo.2006.03.004

Hints, O., Killing, M., MÄNNIK, P. \& NestoR, V. 2006. Frequency patterns of chitinozoans, scolecodonts, and conodonts in the upper Llandovery and lower Wenlock of the Paatsalu core, western Estonia. Proceedings of the Estonian Academy of Sciences, Geology 55, 128-155.

Hints, R., KiRSIMÄE, K., SOMElaR, P., KAllaste, T. \& KiIPLI, T. 2008. Multiphase Silurian bentonites in the Baltic Palaeobasin. Sedimentary Geology 209, 69-79.

DOI 10.1016/j.sedgeo.2008.06.009

Hoernle, K., Tilton, G., LE BAS, M.J., DugGen, S. \& GARBESHÖNBERG, D. 2002. Geochemistry of oceanic carbonatites compared with continental carbonatites: mantle recycling of oceanic crustal carbonate. Contributions to Mineralogy and Petrology 142, 520-542. DOI 10.1007/s004100100308

INANLI, F.Ö., HuFF, W.D. \& BERGSTRÖM, S.M. 2009. The Lower Silurian (Llandovery) Osmundsberg K-bentonite in Baltoscandia and the British Isles: Chemical fingerprinting and regional correlation. GFF 131, 269-279.

DOI 10.1080/11035890903243251

KALJO, D. \& EINASTO, R. 1990. Locality 8:1 Päri outcrop, 179-180. In KALJO, D. \& NESTOR, H. (eds) Field Meeting, Estonia 1990. An Excursion Guidbook. Institute of Geology Estonian Academy of Sciences, Tallinn.

KitPli, T., Einasto, R., Kallaste, T., Nestor, V., Perens, H. \& SIIR, S. 2011. Geochemistry and correlation of volcanic ash beds from the Rootsiküla Stage (Wenlock-Ludlow) in the eastern Baltic. Estonian Journal of Earth Sciences 60, 207-219. DOI 10.3176/earth.2011.4.02

Kitpli, T., Jeppsson, L., Kallaste, T. \& Söderlund, U. 2008a. Correlation of Silurian bentonites from Gotland and the eastern Baltic using sanidine phenocryst composition, and biostratigraphical consequences. Journal of the Geological Society 165, 211-220.

DOI 10.1144/0016-76492006-095

KiIPli, E., Kallaste, T. \& KiIPli, T. 2000a. Hematite and goetite in Telychian marine red beds of the East Baltic. GFF 122, 281-286. DOI 10.1080/11035890001223281

KiIPLI, T., KALlaste, T. \& NeSTOR, V. 2010a. Composition and correlation of volcanic ash beds of Silurian age from the eastern Baltic. Geological Magazine 147, 895-909.

DOI 10.1017/S0016756810000294 
KiIPLI, T., KALlaste, T., Nestor, V. \& LOYdELl, D.K. 2010b. Integrated Telychian (Silurian) K-bentonite chemostratigraphy and biostratigraphy in Estonia and Latvia. Lethaia 43, 32-44. DOI 10.1111/j.1502-3931.2009.00162.x

KIIPLI, E., KIIPLI, T. \& KALlASTE, T. 2000b. Early diagenetic chalcopyrite occurrences in Telychian marine red beds of West Estonia and West Latvia. Proceedings of the Estonian Academy of Sciences, Geology 49, 294-307.

KiIPLI, E., KiIPLI, T. \& KALlaste, T. 2006. Identification of O-bentonite in deep shelf sections with implication on stratigraphy and lithofacies, East Baltic Silurian. GFF 128, 255-260. DOI 10.1080/11035890601283255

KiIPl, T., KiIPli, E., Kallaste, T., Hints, R., SOMElar, P. \& KIRSIMÄE, K. 2007. Altered volcanic ash as an indicator of marine environment, reflecting $\mathrm{pH}$ and sedimentation rate example from the Ordovician Kinnekulle bed of Baltoscandia. Clays and Clay Minerals 55, 177-188.

DOI 10.1346/CCMN.2007.0550207

KiIPLI, T., ORLOVA, K., KIIPLI, E. \& Kallaste, T. 2008b. Use of immobile trace elements for the correlation of Telychian bentonites on Saaremaa Island, Estonia, and mapping of volcanic ash clouds. Estonian Journal of Earth Sciences 57, 39-52. DOI 10.3176/earth.2008.1.04

KiIPli, T., SoesoO, A., Kallaste, T. \& KiIPli, E. 2008c. Geochemistry of Telychian (Silurian) K-bentonites in Estonia and Latvia. Journal of Volcanology and Geothermal Research 171, 45-58. DOI 10.1016/j.jvolgeores.2007.11.005

LEFEBVRE, J.J. \& GASPARRINI, C. 1980. Florencite, an occurrence in the Zairian copperbelt. Canadian Mineralogist 18, 301-311.

LOYDELL, D.K. 2012. Graptolite biozone correlation charts. Geological Magazine 149, 124-132. DOI 10.1017/S0016756811000513

LOYDELL, D.K. \& MALETZ, J. 2002. Isolated Monograptus gemmatus from the Silurian of Osmundsberget, Sweden. GFF 124, 193-196. DOI 10.1080/11035890201244193

LOYDELL, D.K., MÄNNIK, P. \& NESTOR, V. 2003. Integrated biostratigraphy of the lower Silurian of the Aizpute-41 core, Latvia. Geological Magazine 140, 205-229. DOI 10.1017/S0016756802007264

MCLENNAN, S.M. 1989. Rare earth elements in sedimentary rocks: influence of provenance and sedimentary processes, 169-200. In LIPIN, B.R. \& MCKAY, G.A. (eds) Geochemistry and Mineralogy of Rare Earth Elements. Reviews in Mineralogy 21.

MotUZA, V., RADZEVICIUS, S. \& PAŠKEVICIUS, J. 2002. Influence of Caledonic Volcanic activity for marine paleoenviroment: evidence from the Llandoverian graptolites of Baltic Sedimentary Basin, 132-134. In SATKŪNAS, J. \& LAZAUSKIENE, J. (eds) The Fifth Baltic Stratigraphical Conference "Basin Stratigraphy - Modern Methods and Problems". Vilnius.

MourÃo, C., MATA, J., DOUCElance, R., MAdeira, J., Brum DA SILVEIRA, A., SILVA, L.C. \& MOREIRA, M. 2010. Quaternary extrusive calciocarbonatite volcanism on Brava Island (Cape Verde): A nephelinite-carbonatite immicibility product. Journal of African Earth Sciences 56, 59-74.

DOI 10.1016/j.jafrearsci.2009.06.003

NAGY, G., Draganits, E., DEMÉNY, A., PANTÓ, G. \& ÁrKAI, P. 2002. Genesis and transformation of monazite, florencite and rhabdophane during medium grade metamorphism: examples from the Sopron Hills, Eastern Alps. Chemical Geology 191, 25-46. DOI 10.1016/S0009-2541(02)00147-X

Nelson EBy, G., LlOyd, F.E. \& WoOlley, A.R. 2009. Geochemistry and petrogenesis of the Fort Portal, Uganda, extru- sive carbonatite. Lithos 113, 785-800.

DOI 10.1016/j.lithos.2009.07.010

NeSTOR, H. 1997. Silurian, 89-106. In RAUKAS, A. \& TEEDUMÄE, A. (eds) Geology and Mineral Resources of Estonia. Estonian Academy Publishers, Tallinn.

OGG, J.G. 2004. Status of Divisions of International Geologic Time Scale. Lethaia 37, 183-199. DOI 10.1080/00241160410006492

PAŠKEVIČIUS, J. 1982. Some questions on the distribution, development conditions and correlation of the Silurian fauna in Lithuania and the neighbouring countries. Geologija 3, 17-51. [in Russian]

PAŠKEVIČIUS, J. 1997. The geology of the Baltic republics. 388 pp. Geological Survey of Lithuania, Vilnius.

PeCCERILlo, A. 2005. Plio- Quaternary Volcanism in Italy. Petrology, Geochemistry, Geodynamics. 365 pp. Springer, Berlin, Heidelberg, New York.

RAO, P.D. \& WALSH, D.E. 1997. Nature and distribution of phosphorus minerals in Cook Inlet Coals, Alaska. International Journal of Coal Geology 33, 19-42. DOI 10.1016/0166-5162(95)00045-3

RASMUSSEN, B. 1996. Early diagenetic REE phosphate minerals (florencite, gorceixite, grandallite and xenotime) in marine sandstones: a major sink for oceanic phosphorus. American Journal of Science 296, 601-632. DOI 10.2475/ajs.296.6.601

RAY, D.C. 2007. The correlation of Lower Wenlock Series (Silurian) bentonites from the Lower Hill Farm and Eastnor Park boreholes, Midland Platform, England. Proceedings of the Geologists' Association 118, 175-185.

RAY, D.C., COllingS, A.V.J., WORTON, G.J. \& JONES, G. 2011. Upper Wenlock bentonites from Wren's Nest Hill, Dudley; comparisons with prominent bentonites along Wenlock Edge, Shropshire, England. Geological Magazine 148, 670-681. DOI 10.1017/S0016756811000288

ROLLINSON, H. 1993. Using geochemical data: evaluation, presentation, interpretation. 352 pp. Longman Scientific \& Technical, Harlow.

RIBEIRO, C.C., BROD, J.A., JUNGUEIRA-BROD, T.C., GASPAR, J.C. \& PETRINOVIC, I.A. 2005. Mineralogical and field aspects of magma fragmentation deposits in a carbonate-phosphate magma chamber: evidence from the Catalão I complex, Brazil. Journal of South American Earth Sciences 18, 355-369. DOI 10.1016/j.jsames.2004.11.004

SHIELDS, G. \& STILLE, P. 2001. Diagenetic constraints on the use of cerium anomalies as palaeoseawater redox proxies: an isotopic and REE study of Cambrian phosphorites. Chemical Geology 175, 29-48. DOI 10.1016/S0009-2541(00)00362-4

SNÄLL, S. 1977. Silurian and Ordovician bentonites of Gotland (Sweden). Stockholm Contributions in Geology 31(1), 1-80.

ŠTORCH, P. \& KRAFT, P. 2009. Graptolite assemblages and stratigraphy of the lower Silurian Mrákotín Formation, Hlinsko Zone, $\mathrm{NE}$ interior of the Bohemian Massif (Czech Republic). Bulletin of Geosciences 84, 51-74. DOI 10.3140/bull.geosci.1077

WARD, C.R. 2002. Analyses and significance of mineral matter in coal seams. International Journal of Coal Geology 50, 135-168. DOI 10.1016/S0166-5162(02)00117-9

Xu, C., Campbell, I.H., Allen, C.M., Chen, Y.J., Huang, Z.L., QI, L., ZHANG, G.S. \& YAN, Z.F. 2008. U-Pb zircon age, geochemical and isotopic characteristics of carbonatite and syenite complexes from the Shaxiongdong, China. Lithos 105, 118-128. DOI 10.1016/j.lithos.2008.03.002

ZAITSEV, A.N. \& KeLLER, J. 2006. Mineralogical and chemical transformation of Oldoinyo Lengai natrocarbonatites, Tanzania. Lithos 91, 191-207. DOI 10.1016/j.lithos.2006.03.018 